DOI: https://doi.org/10.24127/ajpm.v10i2.3567

\title{
IMPLEMENTASI MODEL PEMBELAJARAN LEARNING CYCLE 5E TERHADAP HASIL BELAJAR TEMATIK SEKOLAH DASAR
}

\author{
Nelly Astuti ${ }^{*}$, Muncarno $^{2}$ \\ ${ }^{1 *, 2}$ Universitas Lampung, Lampung, Indonesia \\ *Corresponding author. \\ E-mail: $\quad$ nellyastuti45@gmail.com ${ }^{1 *}$ \\ muncarno.muncar@gmail.com $^{2)}$
}

Received 16 February 2021; Received in revised form 03 July 2021; Accepted 05 July 2021

\begin{abstract}
Abstrak
Masalah dalam penelitian ini adalah rendahnya hasil belajar tematik peserta didik kelas IV SDN 11 Metro Pusat. Tujuan penelitian ini adalah untuk mengetahui pengaruh penerapan model pembelajaran learning cycle 5E terhadap hasil belajar tematik peserta didik kelas IV SDN 11 Metro Pusat. Jenis penelitian ini adalah penelitian eksperimen. Desain penelitian yang digunakan yaitu non-equivalen control group design. Populasi penelitian berjumlah 60 orang peserta didik. Sampel penelitian menggunakan sampel jenuh dengan jumlah 60 orang peserta didik. Teknik pengumpulan data dilakukan dengan teknik tes dan non tes. Teknik analisis data yang digunakan adalah dengan menggunakan statistik deskriptif, statistik inferensial berupa uji-t dan untuk melihat besarnya pengaruh penerapan model learning cycle 5E digunakan uji $N$-Gain. Hasil penelitian menunjukkan terdapat pengaruh yang signifikan pada penerapan model Learning Cycle 5E terhadap hasil belajar peserta didik. Selain itu, pengaruh penerapan model learnign cycle 5E masuk dalam kategori sedang, yang artinya terdapat peningkatan hasil belajar peserta didik secara signifikan dan memenuhi katogeri sedang.
\end{abstract}

Kata kunci: Hasil belajar; learning cycle 5E; tematik.

\begin{abstract}
The problem in this study is the low thematic learning outcomes of grade IV students at SDN 11 Metro Pusat. The purpose of this study was to determine the positive and significant effect on the application of the $5 E$ learning cycle learning model on the thematic learning outcomes of students in grade IV at SDN 11 Metro Pusat. This type of research is experimental research. The research design used is nonequivalent control group design. The study population numbered 60 students. The research sample uses saturation with a total of 60 students. Data collection techniques are done by using test and non-test techniques. The data analysis of this research are descriptive statistic, inferensial statistic by using t-test, and N-Gain Score Analysis. The results showed a significant effect on the application of the Learning Cycle $5 E$ model to student learning outcomes. Beside that, learning cycle $5 E$ model get middle score from $\mathrm{N}$-Gain Score Analysis. It means that, there is a increasing score significantly.
\end{abstract}

Keywords: 5 E learning cycle; learning outcomes; thematic.

This is an open access article under the Creative Commons Attribution 4.0 International License

\section{PENDAHULUAN}

Pendidikan adalah proses mengubah individu menjadi makhluk yang lebih baik dan beradab secara sadar dan terencana. Berdasarkan Undang-undang Nomor 20 Tahun 2003, Pendidikan adalah usaha sadar dan terencana untuk mewujudkan suasana belajar dan proses pembelajaran agar peserta didik secara aktif mengembangkan potensi dirinya untuk memiliki kekuatan spiritual keagamaan, pengendalian diri, kepribadian, kecerdasan, dan akhlak mulia, serta keterampilan yang 
diperlukan dirinya, masyarakat, bangsa dan negaranya (Pemerintah Republik Indonesia, 2003).

Berdasarkan definisi pendidikan yang telah dijelaskan pada UU No 20 Tahun 2003, dilakukan pembaharuan dalam bidang pendidikan dasar khususnya di jenjang sekolah dasar. Pembaharuan tersebut terlihat dengan diberlakukannya pembelajaran secara tematik. Secara umum, karakteristik khas dari pembelajaran tematik adalah pembelajaran terpadu yang menggunakan tema untuk mengaitkan beberapa mata pelajaran sehingga dapat memberikan pengalaman bermakna kepada peserta didik (Haji, 2015).

Implementasi pembelajaran tematik mengalami beberapa hambatan, baik dari segi pendidik maupun peserta didik. Berdasarkan penelitian yang telah dilakukan diperoleh bahwa kemampuan pendidik dalam melaksanakan pembelajaran tematik cukup rendah. Hal ini terliaht dari kemampuan pendidik dalam menyusun rencana pelaksanaan pembelajaran (RPP), kemampuan dalam melaksanakan pembelajaran, dan kemampuan dalam mengevaluasi pembelajaran (Suwardi, 2015).

Hal serupa juga dipaparkan dalam penelitian lain yang menyimpulkan bahwa hambatan lain yaitu pendidik lebih menekankan pada penilian hasil dari pada penilaian proses (Pratiwi \& Widagdo, 2017). Hasil ini menunjukkan bahwa perlu adanya proses penyesuaian dalam pelaksanaan pembelajaran tematik. Akibat dari adanya kendala dalam pelaksanaan pembelajaran, salah satunya adalah rendahnya hasil belajar peserta didik.

Berdasarkan hasil observasi, diperoleh informasi bahwa pada sekolah yang dijadikan lokasi penelitian telah menerapkan kurikulum 2013. Akan tetapi, penerapan kurikulum 2013 belum maksimal. Hal ini terlihat dari rendahnya hasil belajar peserta didik. Berdasarkan hasil observasi, wawancara, dan dokumentasi di Sekolah Dasar. Hasil belajar peserta didik pada penilaian tengah semester ganjil tahun pelajaran 2019/2020, masih ada peserta didik yang belum mencapai ketuntasan. Peserta didik mencapai KKM pada kelas IV A yaitu 12 peserta didik atau $41 \%$ yang tuntas dan peserta didik yang tidak tuntas 17 peserta didik atau 59\% dari 29 peserta didik, sedangkan nilai yang tuntas di kelas IV B yaitu 9 peserta didik atau 29\% yang tuntas dan peserta didik yang tidak tuntas 22 peserta didik atau $71 \%$ dari 31 peserta didik.

Rendahnya hasil belajar ataupun ketuntasan belajar dipengaruhi oleh banyak faktor. Salah satu faktor yang mungkin adalah penggunaan model pembelajaran yang belum tepat. Berdasarkan hasil observasi, peserta didik cenderung kurang aktif selama pembelajaran. Aktivitas belajar sangat diperlukan oleh peserta didik untuk mendapatkan hasil belajar yang maksimal karena ketika peserta didik hanya pasif atau hanya menerima dari pendidik maka akan ada kecenderungan peserta didik unutk cepat melupakan apa yang telah dipelajari (Rizana, 2017). Oleh karena itu, perlu ada perubahan dalam proses pembelajaran khususnya model pembelajaran yang digunakan.

Salah satu model pembelajaran yang dapat mengakomodasi aktivitas belajar peserta didik adalah model Lerning Cycle 5E. Pembelajaran learning cycle memberikan kesempatan kepada peserta didik untuk mengasimilasi infomrasi dengan cara mengeksplorasi lingkungan, mengakomodasi informasi dengan cara mengembangkan sebuah konsep, 
mengorganisasikan informasi dan menghubungkan konsep-konsep baru dengan menggunakan atau memperluas konsep yang dimiliki untuk menjelaskan suatu fenomena yang berbeda (Nur \& Noviardila, 2021).

Hasil penelitian lain juga menunjukkan bahwa penggunaan model pembelajaran learning cycle 5E dapat memberikan pengaruh yang positif terhadap hasil belajar peserta didik ((Yunita \& Wijayanti, 2020); (Nugroho \& Sutriyono, 2018); (Arvella, 2020); (Fitriyani, Sudin, \& Sujana, 2016);(Asthira, Kusmariyatni, \& Margunayasa, 2016)). Melalui penerapan model learning cycle 5E, peserta didik dapat menemukan konsep sendiri yang dipelajari, mencegah terjadinya kesalahan konsep dan memberikan peluang kepada peserta didik untuk menerapkan konsep (Setiawan, Suartama, \& Putri, 2017).

Berdasarkan penjelasan yang telah diberikan, penggunaan model pembelajaran learning cycle 5E dikatakan mampu untuk membantu dalam meningkatkan hasil belajar peserta didik serta dapat memaksimalkan pembelajaran tematik. Oleh karena itu, penelitian ini bertujuan untuk melihat pengaruh penggunaan model pembelajaran learning cycle $5 \mathrm{E}$ terhadap hasil belajar peserta didik kelas IV SDN 11 Metro Pusat.

\section{METODE PENELITIAN}

Jenis penelitian yang dilakukan adalah penelitian kuantitatif dengan pendekatan eksperimen. Jenis metode yan digunakan adalah eksperimen semu (quasi experiment design). Objek penelitian yang dilakukan ini adalah hasil belajar peserta didik (Y) dan model pembelajaran kooperatif tipe Learning Cycle 5E (X). Subjek penelitian adalah peserta didik kelas IV SD Negeri 11 Metro Pusat.

Rancangan desain penelitian yang digunakan adalah non-equivalent control group design. Desain nonequivalen control group design menggunakan 2 kelompok, yaitu kelompok kelas eksperimen dan kelompok kelas kontrol. Kelas IVB sebagai kelas eksperimen (menerapkan model pembelajaran learning cycle 5E) dan kelas IVA sebagai kelas kontrol.

Populasi pada penelitian ini adalahseluruh peserta didik kelas IV SD Negeri 11 Metro Pusat. Jumlah total populasi sebanyak 60. Teknik pengambilan sampel dalam penelitian ini menggunakan nonprobability sampling dan purposive sampling. Jenis sampel yang diambil dalam penelitian ini adalah sampel jenuh.

Teknik yang digunakan untuk mengumpulkan keseluruhan data yang berkaitan dengan penelitian ini adalah teknik nontes dan teknik tes. Teknik nontes yang digunakan adalah observasi wawancara, angket, dokumentasi. Observasi penelitian ini dilakukan dengan mengamati keterlaksanaan penggunaan model pembelajaran kooperatif tipe Learning Cycle 5E terhadap aktivitas dan hasil belajar. Teknik wawancara digunakan untuk mengumpulkan data empiris mengenai proses pembelajaran di kelas IV. Teknik dokumentasi digunakan untuk mengumpulkan nilai mid semester peserta didik kelas IV, sejarah sekolah, peraturan-peraturan, laporan kegiatan, foto-foto, dan data lainnya yang relevan dengan penelitian.

Teknik tes digunakan untuk mengumpulkan data berupa nilai hasil belajar peserta didik pada ranah kognitif, dan untuk mengetahui sejauh mana tingkat penguasaan peserta didik dalam pembelajaran matematika. 
Bentuk tes yang diberikan berupa soal pilihan jamak.

Data yang dianalisis dalam penelitian ini adalah data kuantitatif, yaitu nilai ranah kognitif pada hasil kemampuan akhir yang diperoleh dari nilai posttest. Untuk mengetahui peningkatan pengetahuan (N-Gain), menggunakan rumus:

$$
\mathbf{G}=\frac{\text { skor postest-skor pretest }}{\text { skor maksimum-skor pretest }}
$$

Teknik analisis data pada penelitian ini adalah uji normalitas, uji homogenitas dan uji hipotesis.

1) Uji Normalitas

Uji normalitas pada penelitian ini menggunakan rumus chi kuadrat sebagai berikut:

$$
\chi^{2}=\sum_{i=1}^{k} \frac{\left(f_{o}-f_{h}\right)^{2}}{f_{h}}
$$

Keterangan:

$\chi^{2}=$ Nilai Chi Kuadrat hitung

$\boldsymbol{f}_{\boldsymbol{o}}=$ Frekuensi yang diperoleh

$\boldsymbol{f}_{\boldsymbol{h}}=$ Frekuensi yang diharapkan

Kaidah keputusan:

Jika $\chi^{2}{ }_{\text {hitung }} \leq \chi^{2}$ tabel, artinya distribusi data dinyatakan normal dan begitu pula sebaliknya.

2) Uji homogenitas

Uji homogenitas dilakukan dengan menggunakan uji-F dengan rumus:

$$
\mathbf{F}=\frac{\text { Varian terbesar }}{\text { Varian terkecil }}
$$

Kaidah keputusan:

jika $F_{\text {hitung }}<F_{\text {tabel }}$ maka disimpulkan bahwa data berasal dari populasi yang homogen, begitu pula sebaliknya.

3) Analisis Hipotesis

Analisis hipotesis yang dilakukan yaitu menggunakan t-test pooled varians. Kaidah keputusannya, yaitu jika thitung $>$ $t_{\text {tabel }}$ berarti $\mathrm{H}_{\mathrm{a}}$ diterima, artinya
"Terdapat pengaruh yang signifikan pada penggunaan model pembelajaran kooperatif tipe Learning Cycle 5E terhadap hasil belajar tematik peserta didik kelas IV di Sekolah Dasar."

\section{HASIL DAN PEMBAHASAN}

Setelah dilakukan pengumpulan data, diperoleh data pretest dan posstest seperti yang ditampilkan pada Tabel 1 dan 2.

Tabel 1. Distribusi frekuensi nilai pretest kelas eksprimen dan kelas kontrol.

\begin{tabular}{lccc}
\hline \multirow{2}{*}{ No. } & Interval & \multicolumn{2}{c}{ Frekuensi } \\
\cline { 3 - 4 } & Kelas & Eksperimen & Kontrol \\
\hline 1 & $35-43$ & 6 & 0 \\
2 & $44-50$ & 5 & 2 \\
3 & $51-67$ & 5 & 9 \\
4 & $68-74$ & 6 & 7 \\
5 & $75-81$ & 4 & 7 \\
$\mathbf{6}$ & $82-88$ & 4 & 4 \\
7 & $89-95$ & 0 & 1 \\
\hline Jumlah & $\mathbf{3 0}$ & $\mathbf{3 0}$ \\
\hline Rata-rata & $\mathbf{5 6 , 6 7}$ & $\mathbf{6 5 , 6 7}$ \\
\hline Ketuntasan & $\mathbf{1 3 , 3 3 \%}$ & $\mathbf{7 3 , 3 3 \%}$ \\
\hline
\end{tabular}

Tabel 2. Distribusi frekuensi nilai posttest kelas eksperimen dan kelas kontrol

\begin{tabular}{cccc}
\hline \multirow{2}{*}{ No. } & Interval & \multicolumn{2}{c}{ Frekuensi } \\
\cline { 3 - 4 } & Kelas & Eksperimen & Kontrol \\
\hline 1 & $44-50$ & 5 & 2 \\
2 & $51-67$ & 5 & 9 \\
3 & $68-74$ & 6 & 7 \\
4 & $75-81$ & 4 & 7 \\
$\mathbf{5}$ & $82-88$ & 4 & 4 \\
$\mathbf{6}$ & $89-95$ & 0 & 1 \\
\hline Jumlah & $\mathbf{3 0}$ & $\mathbf{3 0}$ \\
\hline Rata-rata & $\mathbf{7 4 , 5 0}$ & $\mathbf{7 0 , 8 3}$ \\
\hline Ketuntasan & $\mathbf{7 3 , 3 3 \%}$ & $\mathbf{5 3 , 3 3 \%}$ \\
\hline
\end{tabular}

Berdasarkan hasil pada Tabel 1 dan Tabel 2, dapat dilihat pada peroleh nilai terendah setelah posttest mengalami pergeseran. Setelah dilakukan proses pembelajaran dapat 
dikatakan terjadi peningkatan hasil belajar baik dikelas kontrol maupun dikelas eksperimen. Hasil lain yang menunjukkan bahwa adanya perubahan signifikas setelah dilakukan pembelajaran learning cycle 5E adalah nilai rata-rata dan persentase ketuntasan. Terlihat bahwa rata-rata dan persentese ketuntasan kelas eksperimen lebih tinggi dari pada kelas kontrol khususnya pada hasil posttest.

Hasil yang ditunjukkan pada Tabel 1 dan 2 masih perlu dianalisis lebih lanjut untuk mengetahui apakah pengaruh yang diberikan oleh model pembelajaran learning cycle 5E cukup siginifikan dalam meningkatkan hasil belajar peserta didik. Oleh karena itu, harus dilanjutkan dengan uji hipotesis yang terlebih dahulu didahului dengan uji prasyarat yang meliputi uji normalitas dan uji homogenitas.

Hasil perhitungan uji normalitas pada data pretest kelas eksperimen diperoleh $\chi_{\text {hitung }}^{2}<\chi_{\text {tabel }}^{2}$ yaitu 4,570< 11,070 hal tersebut menunjukkan bahwa data pretest kelas eksperimen berdistribusi normal). Perhitungan uji normalitas pada data posttest kelas eksperimen diperoleh $\chi_{\text {hitung }}^{2}<\chi_{\text {tabel }}^{2}$ yaitu $7,003<11,070$ hal tersebut menunjukkan bahwa data posttest kelas eksperimen berdistribusi normal. Hasil perhitungan uji normalitas secara manual pada data pretest kelas kontrol diperoleh $\chi_{\text {hitung }}^{2}<\chi_{\text {tabel }}^{2}$ yaitu 7,284< 11,070 hal ini menunjukkan bahwa data pretest kelas kontrol berdistribusi normal). Hasil perhitungan uji normalitas untuk data posttest kelas kontrol diperoleh $\chi_{\text {hitung }}^{2}<\chi_{\text {tabel }}^{2}$ yaitu $6,024<11,07$ hal ini menunjukkan bahwa data posttest kelas kontrol berdistribusi normal.

Setelah diperoleh hasil bahwa data berdistribusi normal, maka dilanjutkan dengan uji homogenitas.
Hasil perhitungan didapat nilai $F_{\text {hitung }}$ untuk pretest sebesar 1,77 sedangkan $\mathrm{F}_{\text {hitung }}$ posttest sebesar 1,17. Nilai kedua $\mathrm{F}_{\text {hitung }}<\mathrm{F}_{\text {tabel }}$ yaitu 1,88. Berdasarkan kedua nilai $\mathrm{F}$ tersebut maka dapat disimpulkan bahwa populasi memiliki varian yang sama atau homogen.

Hasil uji prasyarat telah menunjukkan bahwa data berdistribusi normal dan berasal dari populasi yang homogen. Oleh karena itu, uji hipotesis dapat dilakukan. Pengujian hipotesis dengan menggunakan uji-t. Rumus yang digunakan adalah rumus t-tes pooled varians. Menentukan $\mathrm{t}_{\text {tabel }}$ dengan $\mathrm{dk}=$ $(30+30-2)=58$ dengan taraf signifikasi $5 \%$ maka didapat $\mathrm{t}_{\text {tabel }}=2,00$, dan dengan menggunakan rumus t-test pooled varians diperoleh data $t_{\text {hitung }}$ 3,03 . Sehingga $t_{\text {hitung }}=3,03>t_{\text {tabel }}=$ 2,00 berarti $\mathrm{H}_{\mathrm{a}}$ diterima, artinya "Terdapat pengaruh yang signifikan pada penggunaan model pembelajaran kooperatif tipe Learning Cycle 5E terhadap hasil belajar tematik peserta didik kelas IV di Sekolah Dasar."

Hasil uji hipotesis menunjukkan bahwa terdapat pengeruh signifikan dari penggunaan model pembelajaran learning cycle 5E. Langkah selanjutnya, yaitu menganali-sis seberapa besar pengaruh learning cycle $5 \mathrm{E}$ terhadap hasil belajar peserta didik. Oleh karena itu, selanjutnya dilakukan uji $N$-Gain. Rata-rata hasil dari uji $N$ Gain dapat dilihat pada Tabel 3.

Tabel 3. Rata-rata n-gain kelas eksperimen dan kelas kontrol

\begin{tabular}{cccc}
\hline Kelas & $\begin{array}{c}\text { Rata-rata } \\
\boldsymbol{N} \text {-Gain }\end{array}$ & Kategori Selisih \\
\hline Eksperimen & 0,49 & Sedang & \multirow{2}{*}{0,21} \\
Kontrol & 0,28 & Rendah & \\
\hline
\end{tabular}

Berdasarkan Tabel 3, diperoleh hasil bahwa rata-rata $N$-Gain untuk kelas eksperimen lebih tinggi yaitu 
memenuhi katogeri sedang. Hal ini menunjukkan bahwa terjadi peningkatan hasil belajar peserta didik dilihat dari nilai pretest dan nilai posttest. Hasil ini juga menunjukkan bahwa penerapan model learning cycle 5E memberikan pengaruh yang signifikan terhadap hasil belajar peserta didik.

Hasil lain yang ditunjukkan adalah selisih rata-rata nilai $N$-Gain antara kelas eksperimen dan kelas kontrol. Hal ini mendukung bahwa model pembelajaran learning cycle $5 \mathrm{E}$ lebih baik untuk diimplementasikan dalam pembelajaran dari pada pembelajaran yang selama ini dilaksanakan oleh pendidik di SD Negeri 11 Metro Pusat.

Hasil penelitian yang diperoleh relevan dengan penelitian sebelumnya yaitu hasil belajar peserta didik meningkat setelah dilakukan pembelajaran dengan menggunakan model learning cycle 5E (Yunita \& Wijayanti, 2020). Peningkatan hasil belajar peserta didik juga didasari oleh langkah-langkah 5E. Pada tahap eksplorasi, peserta didik dilatih untuk mengevaluasi ide yang telah dituliskan, berpendapat, bertanya, dan menyampaikan ide kepada orang lain (Purnamasari, Aryuna, \& Maryono, 2017).

Sejalan dengan hal tersebut, pada penelitian lain disebutkan pula bahwa penggunaan model learning cycle 5E membentu peserta didik untuk meyakinkan dirinya untuk mampu menyelesaikan setiap masalah yang dihadapi (Hakim, Wadu, \& Hasanah, 2020). Hasil penelitian lain pun sejalan dengan mengatakan bahwa model pembelajaran learning cycle $5 \mathrm{E}$ menuntut peserta didik untuk berpartisipasi secara aktif dan bukan lagi hanya sebagai pendengar (Nugroho \& Sutriyono, 2018). Pembelajaran meningkat setelah diterapkan model learning cycle $5 \mathrm{E}$ yang tercermin pada peningkatan proses berupa peningkatan aktivitas belajar (Yuliati, 2015).

Peningkatan aktivitas serta kepercayaan peserta didik dalam mengikuti pembelajaran maupun menyelesaikan permasalahan menjadi bekal penting untuk dapat meningkatkan pemahaman yang pada akhirnya akan meningkatkan hasil belajar peserta didik. Penggunaan model pembelajaran learning cycle $5 \mathrm{E}$ terhadap pembelajaran telah mampu memberikan pengaruh positif, sehingga pembelajaran menjadi lebih aktif dan efektif.

\section{KESIMPULAN DAN SARAN}

Berdasarkan hasil analisis data dan pembahasan, dapat disimpulkan bahwa terdapat pengaruh yang positif dan signifikan pada penggunaan model pembelajaran kooperatif tipe Learning Cycle 5E terhadap hasil belajar tematik peserta didik kelas IV Sekolah Dasar. Pengaruhnya dapat dilihat pada perbedaan hasil belajar kelas eksperimen dan kelas kontrol. Perbedaan ini didasari oleh meningkatnya aktivitas belajar peserta didik yang menggunakan model learning cycle 5E. Hal ini juga berpengaruh terhadap keyakinan peserta didik dalam menyelesaikan permasalahan.

Adapun saran untuk penelitian selanjutnya, yaitu untuk dapat menerapkan model pembelajaran kooperatif tipe Learning Cycle 5E dalam pembelajaran yang bervariasi. Selain itu, hendaknya dapat dikolaborasikan dengan pendekatan, strategi, dan model pembelajaran yang lain sesuai dengan tujuan pembelajaran. 
DOI: https://doi.org/10.24127/ajpm.v10i2.3567

\section{DAFTAR PUSTAKA}

Arvella, S. N. (2020). Pengaruh Model Learning Cycle 5E Terhadap Kemampuan Berpikir Kritis Siswa Kelas V Budi Luhur Elementary Materi Ekosistem. UIN Syarif HIdayatullah, Jakarta.

Asthira, I. W., Kusmariyatni, N., \& Margunayasa, I. G. (2016). Pengaruh Model Pembelajaran Learning Cycle “ 5E " Terhadap Hasil Belajar IPA Siswa Kelas V di Gugus III. E-Journal PGSD Universi, 4(1), 1-9.

Fitriyani, S., Sudin, A., \& Sujana, A. (2016). Penerapan Model Learning Cycle Pada Materi Sumber Daya Alam Untuk Meningkatkan Hasil Belajar Siswa Kelas IVA SDN I Depok Kecamatan Depok Kabupaten Cirebon. Jurnal Pena Ilmiah, 1(1), 511-520.

Haji, S. (2015). Pembelajaran Tematik yang Ideal di SD/MI. Modelling: Jurnal Program Studi PGMI, 3(1), 56-69.

Hakim, A. R., Wadu, L. B., \& Hasanah, L. (2020). Pengaruh Model Pembelajaran Learning Cycle 5E Terhadap Self Efficacy Siswa pada Pembelajaran Tematik Kelas IV SDN Tanjungrejo 5 Kota Malang. Seminar Nasional PGSD UNIKAMA, 4, 385-393. Malang: Universitas Kanjuruhan Malang.

Nugroho, H., \& Sutriyono. (2018). Pengaruh Model Pembelajaran Learning Cycle 5E. Histogram: Jurnal Pendidikan Mateamtika, 2(1), 45-58.

Nur, S. S., \& Noviardila, I. (2021). Kajian Literatur Pengaruh Model Learning Cycle Terhadap Hasil Belajar TEmatik Terpadu. Journal of Education Research, 2(1), 1-5.

Pemerintah Republik Indonesia. $U U$ Nomor 20 Tahun 2003. , Pub. L. No. 4301 (2003).
Pratiwi, R. K., \& Widagdo, A. (2017). Implementasi Pembelajaran Tematik pada Kelas Awal di Sekolah Dasar. Joyful Learning Journal, 6(4), 277284.

Purnamasari, A., Aryuna, D. R., \& Maryono, D. (2017). Penerapan Pembelajaran Learning Cycle 5E Sebagai Upaya untuk Meningkatkan Respon Positif dan Pemahaman Siswa. Jurnal Pendidikan Matematika Dan Matematika (JPMM), 1(6), 17-26.

Rizana, D. P. (2017). Peningkatan Aktivitas Belajar Siswa SD Melalui Pengelolaan Pembelajaran Problem Based Learning. Manajer Pendidikan, 11(2), 193-198.

Setiawan, I. W. P., Suartama, I. K., \& Putri, D. A. W. M. (2017). Pengaruh Model Pembelajaran Learning Cycle 5E Berbantuan Mind Mapping Terhadap Hasil Belajar Matematika. E-Journal PGSD Universitas Ganesha, 5(2), 1-11.

Suwardi. (2015). Kendala Implementasi Pembelajaran Tematik di Madrasah Ibtidaiyah Swasta. Prosiding Semianr Nasional Pendidikan, (November), 267-273. Surakarta: Universitas Sebelas Maret.

Yuliati, Y. (2015). Penerapan Model Learning Cycle 5E untuk Meningkatkan Pembelajaran IPA. Jurnal Cakrawala Pendas, I(1), 5867.

Yunita, \& Wijayanti, R. (2020). Pengaruh Penggunaan Model Pembelajaran Learning Cycle 5E Terhadap Hasil Belajar Siswa Dalam Memecahkan Masalah Matematis Berbentuk Soal Cerita. KEGURU: Jurnal Ilmu Pendidikan Dasar, 4(1), 22-28. 